\title{
THE SIGNIFICANCE OF NUPTIALITY WITH RESPECT TO INTERPRETATION OF SEX DIFFERENCES
}

\author{
BY \\ MURIEL M. JOHNSTONE and MARGERY E. HOSKER \\ From the Department of Medical Statistics, Birmingham University and United Hospitals
}

\section{INTRODUCTION}

Existence of sex differentials with respect to disease in human populations is a matter which deserves investigation both from a practical and from a theoretical viewpoint. At the operational level, their interest scarcely calls for comment; but the biological significance we attach to them is an issue we are prone to dismiss too lightly by undue reliance on experience of laboratory stocks. In one way or another, most human societies are polarized with respect to the prevailing pattern of occupation in which one or other sex is engaged. Hence statistical regularities characteristic of the sex difference may well arise in virtue of hazards peculiar to different occupations in contradistinction to agencies ultimately traceable to the $\mathrm{X}$-chromosome complement.

If a wholly decisive test for discrimination between these possibilities or for evaluation of their relative importance in a given situation is not available, there is at least one framework of comparison relevant to a balanced judgment. On the whole, single females, if adult, have gainful employment outside the home, as do the majority of men. To this extent, we are entitled to expect that sex differences, if attributable to differential occupational risk, will be less obtrusive if we restrict our comparison to unmarried women. This does not mean that a sex differential attributable wholly or largely to circumstances unconnected with constitutional differences will disappear if we confine our comparison to men as a whole and to single women only. We must not disregard the fact that single women and men, if gainfully employed, dominate different trades and professions. For instance, men dominate the heavy industries and single women predominate in domestic and cognate services, including the care of children and the sick.

It is none the less broadly true that the daily regime of the single woman conforms more to that of the male than does that of the married woman. In so far as the morbidity experience of the single woman conforms more to the male pattern we have therefore good grounds for assuming that differencesd which distinguish women as a whole are appreciably? attributable to occupational status. The converse is not true, inasmuch as a difference which distin $-\omega$ guishes the sexes may be associated with an occupa-응 tional hazard almost or wholly restricted to males.

Needless to say any comparison undertaken with this end in view is liable to lead us grossly astray if we do not pay attention to the differential incidence of disease with respect to age. Accordingly $\overrightarrow{x O}$ comparisons of the mortality experience of men with that of women, or of single women with that of married women should take within their scope ao breakdown with regard to age of the relevants populations at risk. This communication is an examination of what materials official statistics of diseaseo supply.

\section{SOURCES OF FIGURES}

For the purpose of this investigation we have had recourse to mortality experience in different coun tries. Morbidity statistics, where they do exist refer only to the section of the community insured for National Health purposes. A population? represented by such a characteristic will exclude? all children, the majority of married women, and all others who are either retired or of independene means. For this reason mortality in England and Wales during the three years round the last census? that is, 1930-1932, was our first target. Canadis is the only other country which provides mortalitye. statistics for each conjugal group at different ages $N$ and other sources of mortality experience cited below were used to provide confirmation of sex differentials disclosed by the mortality statistics of England and Wales, and of Canada. As far as ise compatible with the delimitation of the census yeafe and with the size of the population, mortality rates during the same period have been chosen in each country. Statistics of Canadian mortality during the last war, however, were available and have beent included. All crude figures have been related tof the population given in the mid-year Census of the period reviewed in each country. 
TABLE I

Diseases with a Higher Male Mortality: at Ages Fifteen Years and over

(Female rates as percentage of male rate)

A. ENGLAND AND WALES, 1930-1932

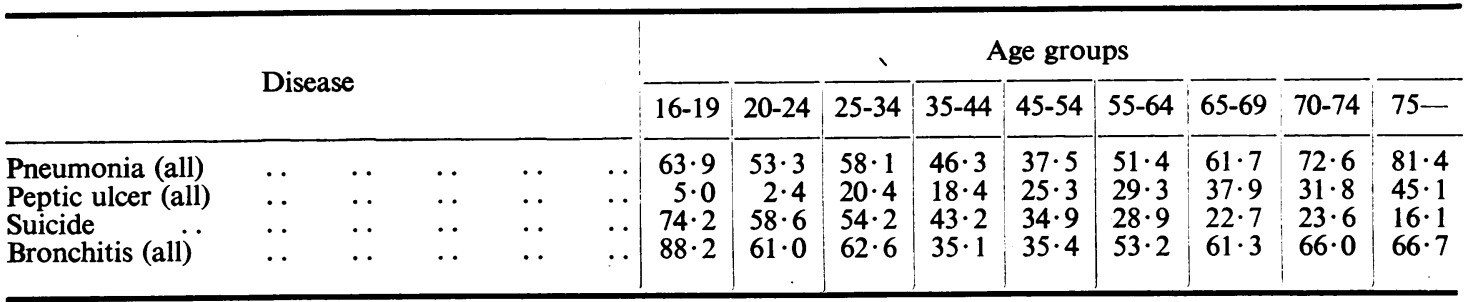

B. CZECHOSLOVAKIA, 1928-1930

\begin{tabular}{|c|c|c|c|c|c|c|c|c|c|c|c|c|c|c|}
\hline \multirow{2}{*}{\multicolumn{3}{|c|}{ r. }} & \multirow{2}{*}{\multicolumn{2}{|c|}{ Disease }} & & & & & & \multicolumn{5}{|c|}{ Age groups } \\
\hline & & & & & & & & & & $15-24$ & $25-39$ & $40-49$ & $50-64$ & $65-$ \\
\hline \multicolumn{2}{|c|}{ Pneumonia (all) } & .. & .. & .. & .. & .. & .. & .. & .. & $82 \cdot 3$ & $94 \cdot 2$ & $74 \cdot 0$ & $80 \cdot 2$ & $88 \cdot 1$ \\
\hline \multicolumn{2}{|c|}{ Peptic ulcer (all) } & . & .. & .. & .. & .. & .. & .. & .. & $10 \cdot 3$ & $27 \cdot \overline{1}$ & $32 \cdot 4$ & $36 \cdot 2$ & $52 \cdot 2$ \\
\hline \multicolumn{2}{|c|}{$\begin{array}{l}\text { Peptic ulcer (all) } \\
\text { Duodenal ulcer }\end{array}$} & .. & .. & .. & .. & .. & .. & .. & .. & - & $20 \cdot 1$ & $19 \cdot 4$ & $35 \cdot 7$ & $75 \cdot 1$ \\
\hline \multirow{2}{*}{\multicolumn{2}{|c|}{$\begin{array}{ll}\text { Gastric ulcer } & \text {.. } \\
\text { Appendicitis } & \text {.. }\end{array}$}} & 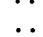 & 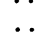 & 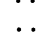 & $\because$. & .. & .. & $\therefore$ & .. & $12 \cdot 2$ & $28 \cdot 3$ & $35 \cdot 7$ & $32 \cdot 1$ & $49 \cdot 8$ \\
\hline & .. & .. & .. & .. & .. & .. & $\because$ & $\because$ & $\therefore$ & $64 \cdot 7$ & $72 \cdot 7$ & $57 \cdot 2$ & $72 \cdot 7$ & $71 \cdot 6$ \\
\hline \multicolumn{2}{|l|}{ Suicide } & .. & .. & .. & .. & .. & .. & .. & .. & $43 \cdot 7$ & $37 \cdot 4$ & $30 \cdot \overline{6}$ & $26 \cdot 6$ & $27 \cdot 3$ \\
\hline \multirow{3}{*}{$\begin{array}{c}\text { Bronchitis } \\
,\end{array}$} & (all) & .. & . & .. & .. & .. & .. & .. & . & $113 \cdot 5$ & $76 \cdot 5$ & $54 \cdot 3$ & $57 \cdot 9$ & $81 \cdot 4$ \\
\hline & (acute) & .. & .. & .. & .. & .. & .. & .. & .. & $100 \cdot 0$ & $152 \cdot 5$ & $122 \cdot 7$ & $63 \cdot 1$ & $99 \cdot 8$ \\
\hline & (chronic) & $\ldots$ & .. & .. & .. & .. & .. & .. & .. & $114 \cdot 8$ & $70 \cdot 7$ & $49 \cdot 5$ & $57 \cdot 5$ & $79 \cdot 4$ \\
\hline
\end{tabular}

C. NEW ZEALAND, 1930-1942

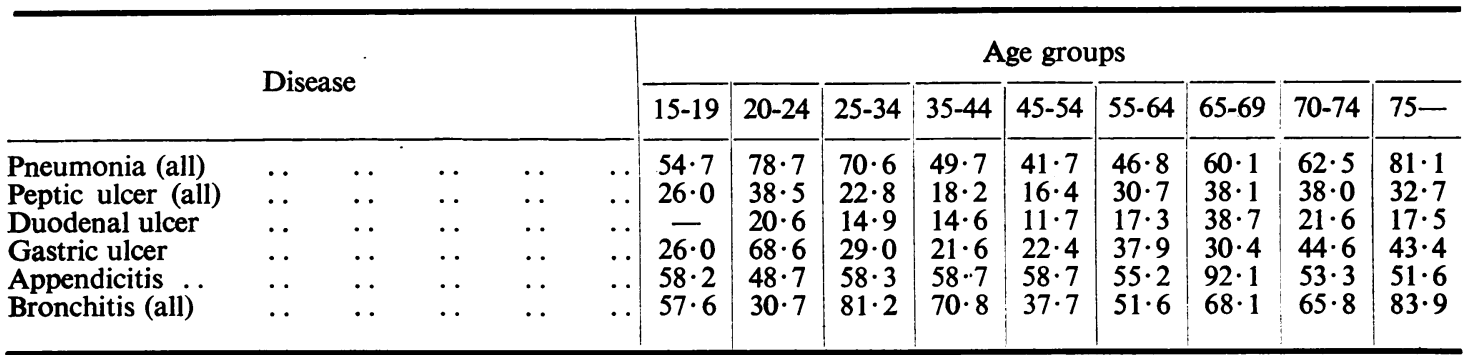

\section{SeX Differentials}

To bring into clearer focus sex differentials arising from differences in occupational status, the adult population has been considered separately. Tables I to V show only those diseases from which males suffered a mortality consistently higher or lower in each country for which statistics were available than that of females at ages 15 and over or less than 15 years. In all these Tables female mortality rates are presented as a percentage of male mortality rates in the same age group.

Outstanding differentials disclosed in Tables $I$ to IV and in Fig. 1 and confirmed by their existence in more than one country are: 
TABLE I-continued.

Diseases with a Higher Male Mortality: at Ages Fifteen Years and over (Female rates as percentage of male rate)

D. U.S.A., 1929-1931

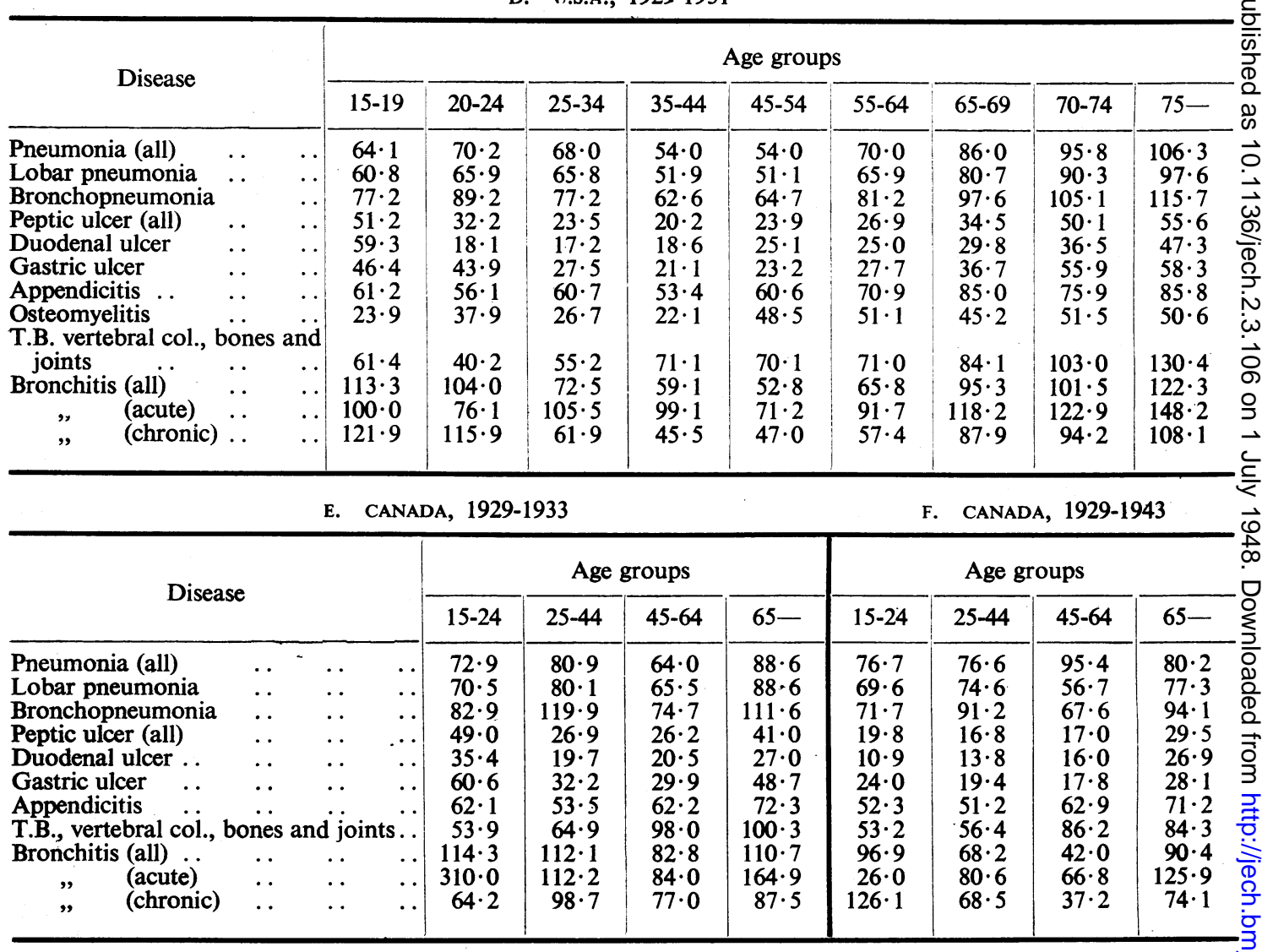

3. Males of less than 15 years only have a higher mortality from acute nephritis. American vital statistics provide figures of mortality with respect to osteomyelitis, which also discloses a sex differential in favour of the female.

4. Adult males have a lower mortality from diseases of the thyroid and parathyroid, from diabetes, and from pernicious anaemia. Unfortunately available public statistics do not contain data with respect to the contribution of each specific disease to the first group total.

5. Young males under the age of 15 years had a lower mortality from whooping-cough.

Mortality rates with respect to respiratory tuberculosis (Table V and Fig. 2) display the familiar picture of an excess of female to male deaths in early adult life and an excess of male to female deaths in middle age and later life. The peak mortality among older men is probably associated with increased risk due to industrial hazards, as a result ${ }^{\circ}$ either of years of work in " dusty " industries, or of increasing strain endured by older men in heavye. industry. Rich (1946) suggests that the compara- N tively high mortality among young women is to some extent influenced by pregnancy and child -0 bearing since they occur more frequently amongw women of less than 30 . He produces a table giving for different States of the U.S.A. the sex differentialo in each age group in association with birth rates andळ with extent of urbanization. Rich concludes:

" In general, then, the states in which a higher female than male mortality extends into the fourth decade tend to be predominantly rural states with a $\frac{\rho}{D}$ relatively high birth rate among females in this agee period; and the states in which the male mortality surpasses that of the female in the fourth decade 
have, in general, a predominantly urban population, with a relatively low birth rate in females in the fourth decade. Certainly, these are by no means the only factors concerned in the local differences in the male-female tuberculosis mortality ratio. Indeed, they may be much less important than other as yet undetermined factors. The purpose in presenting the data . . . is not to pretend to a solution of the problem, but rather to illustrate the need for much more study in the attempt to determine just what the factors are which are responsible for the marked differences in the mortality from tuberculosis in males and females."

It is evident, however, from the figures in Table VII that other influences on tuberculosis mortality among women are sufficiently strong to offset any effect of childbirth to such an extent that single women have an even higher mortality from this disease than those who are married. It may be that there is some selective process in so far as women known to have tuberculosis tend to remain unmarried; but the long latent period of the disease is likely to prevent any selection of this kind from being unduly widespread.

Mortality from tuberculosis of bones and joints presents quite a different picture. It is higher among males of all age groups except the oldest when women have an excess mortality. In Canada, the only country for which figures are available, mortality from this disease is much higher among single women of all ages than among married ones.

In a private communication, Dr. Enid Charles, Director of the Statistical Office of the Birmingham City Corporation, has kindly drawn our attention to sex differentials with respect to mortality from various diseases, published by the Metropolitan Life Insurance Company of New York. Figures cited show differences similar to those appearing in this paper. Comparable statistics extracted from their Bulletin are shown below:

\section{Differences between Married and Single}

\section{WOMEN}

Relevant figures are displayed in Tables VI and VII in which mortality rates among married women are calculated as a percentage of those among single women in the same age groups. . They disclose the following differentials:

1. At all ages married women suffer a higher mortality from cancer of the uterus. Separate statistics for cancer of the cervix and of the corpus uteri were not available.

2. From the age of about 45, married women suffer a higher mortality from diabetes. That the differential is greatest after the childbearing period excludes the possibility of its being a direct effect of pregnancy. We are left with two possible explanations:

(a) that it is an indirect effect of repeated pregnancies in so far as the metabolism of the mother may be upset;

(b) that it is due to a difference in eating habits or in the general environment of married as opposed to single women.

3. Married women have a rather lower mortality from bronchitis and pneumonia.

4. Married women have a conspicuously lower mortality than single women from tuberculosis, peptic ulcers, cancer of the breast, pernicious anaemia, and suicide.

Australian vital statistics provide data with respect to the number of deaths due to cancer at different sites among single women, married women with children, and among childless married women. Surprisingly enough, the ratio of deaths from cancer of the breast to deaths from cancer of the uterus among childless married women is more

Trend of Mortality from Specified Causes among White Persons, by Sex. Ages 1 to 74 Years. Metropolttan

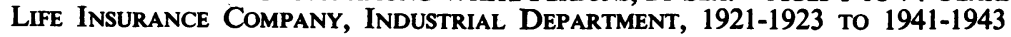

\begin{tabular}{|c|c|c|c|c|c|c|c|c|c|c|}
\hline \multirow{3}{*}{ Cause of death } & & \multicolumn{6}{|c|}{ Average of annual death rates per $100,000^{*}$} & \multirow{2}{*}{\multicolumn{3}{|c|}{ Ratio male to female rate }} \\
\hline & & \multicolumn{3}{|c|}{ White males } & \multicolumn{3}{|c|}{ White females } & & & \\
\hline & & $\begin{array}{l}1921- \\
1923\end{array}$ & $\begin{array}{c}1931- \\
1933\end{array}$ & $\begin{array}{l}1941- \\
1943\end{array}$ & $\begin{array}{l}1921- \\
1923\end{array}$ & $\begin{array}{l}1931- \\
1933\end{array}$ & $\begin{array}{c}1941- \\
1943\end{array}$ & $\begin{array}{l}1921- \\
1923\end{array}$ & $\begin{array}{l}1931- \\
1933\end{array}$ & $\begin{array}{c}1941- \\
1943\end{array}$ \\
\hline $\begin{array}{l}\text { Ulcer of the stomach } \\
\text { Ulcer of the duodenum } \\
\text { Tuberculosis (all forms) } \\
\text { Pneumonia (all forms) } \\
\text { Appendicitis . . . } \\
\text { Diabetes mellitus } \quad \text {. }\end{array}$ & \begin{tabular}{l|}
$\cdots$ \\
$\cdots$ \\
$\cdots$ \\
$\cdots$ \\
$\cdots$
\end{tabular} & $\begin{array}{r}4 \cdot 9 \\
1 \cdot 8 \\
121 \cdot 1 \\
81 \cdot 9 \\
16 \cdot 2 \\
14 \cdot 2\end{array}$ & $\begin{array}{r}6 \cdot 5 \\
3 \cdot 0 \\
73 \cdot 0 \\
64 \cdot 9 \\
16 \cdot 1 \\
13 \cdot 9\end{array}$ & $\begin{array}{r}6 \cdot 7 \\
3 \cdot 1 \\
44 \cdot 2 \\
31 \cdot 4 \\
7 \cdot 2 \\
12 \cdot 9\end{array}$ & $\begin{array}{r}1 \cdot 9 \\
0 \cdot 6 \\
94: 0 \\
63 \cdot 9 \\
11 \cdot 7 \\
21 \cdot 6\end{array}$ & $\begin{array}{r}1 \cdot 5 \\
0 \cdot 5 \\
50 \cdot 1 \\
43 \cdot 1 \\
11 \cdot 2 \\
26 \cdot 6\end{array}$ & $\begin{array}{r}0 \cdot 9 \\
0 \cdot 5 \\
22 \cdot 6 \\
16 \cdot 1 \\
4 \cdot 5 \\
26 \cdot 1\end{array}$ & $\begin{array}{l}2 \cdot 6 \\
3 \cdot 0 \\
1 \cdot 3 \\
1 \cdot 3 \\
1 \cdot 4 \\
0 \cdot 66\end{array}$ & $\begin{array}{l}4 \cdot 3 \\
6 \cdot 0 \\
1 \cdot 5 \\
1 \cdot 5 \\
1 \cdot 4 \\
0 \cdot 52\end{array}$ & $\begin{array}{l}7 \cdot 4 \\
6 \cdot 2 \\
2 \cdot 0 \\
2 \cdot 0 \\
1 \cdot 6 \\
0 \cdot 49\end{array}$ \\
\hline
\end{tabular}

* Standardized for age on the basis of the Standard Million of England and Wales, 1901. 


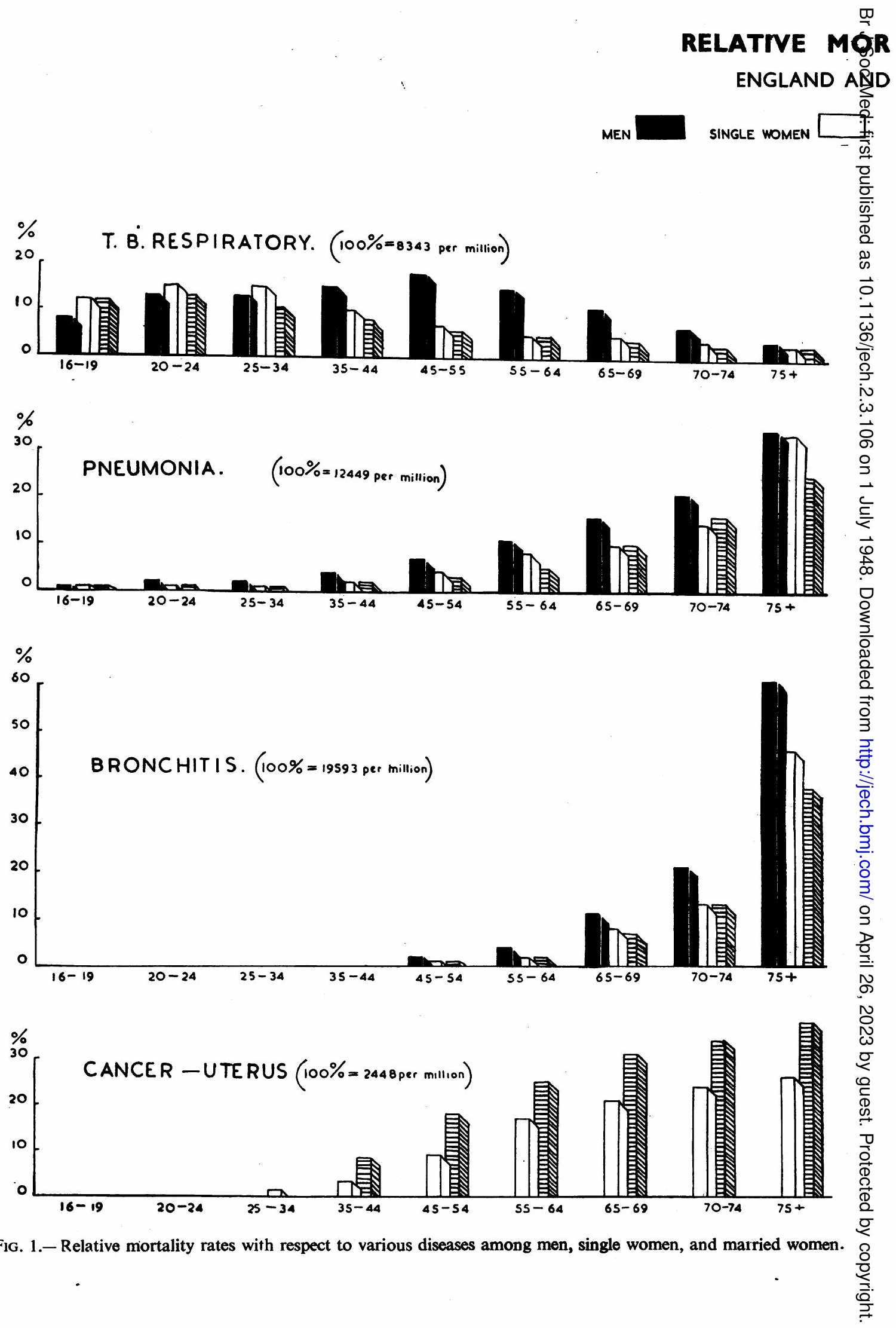




\section{TALITY RATES}

WALES : $1930-32$

MARRIED WOMEN

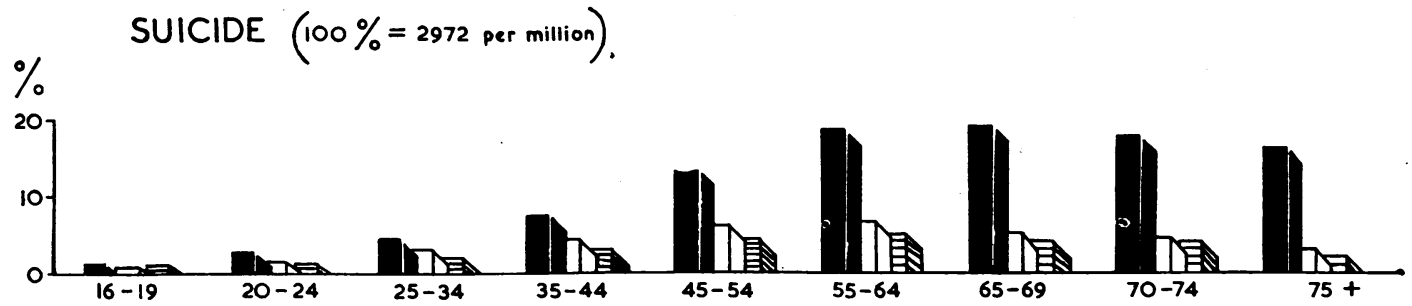

$\%$ PEPTIC ULCER (100\%=2663 per million)
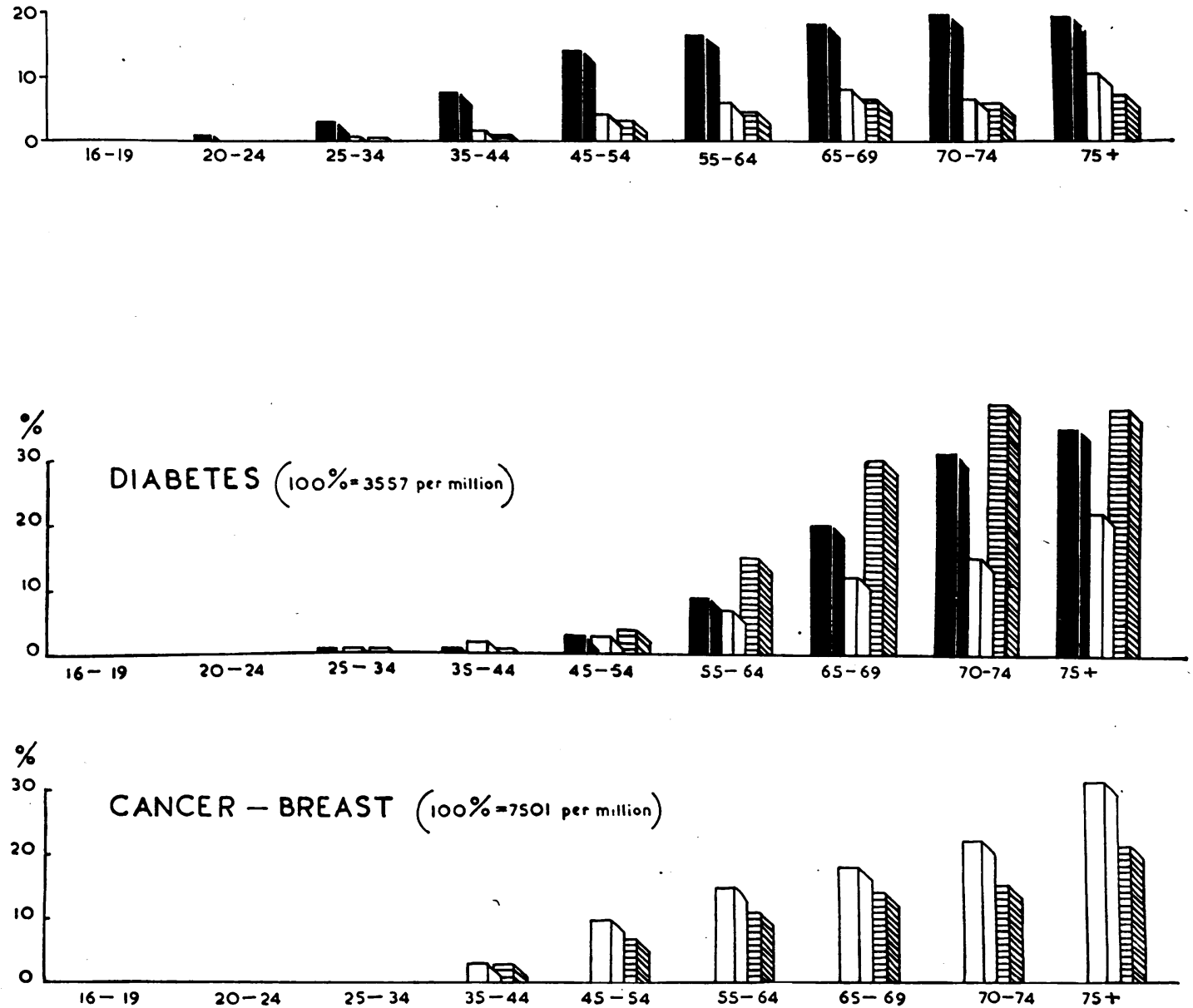

Mortality rates per million population in each age group are shown as a percentage of the sum of all such male rates. 
<smiles>C1CCCCC1</smiles> 
SIGNIFICANCE OF NUPTIALITY

113

RATES FROM TUBERCULOSIS

$100 \%-.-$

RESPIRATORY

VERTEBRAL COLUMN, BONES AND JOINTS
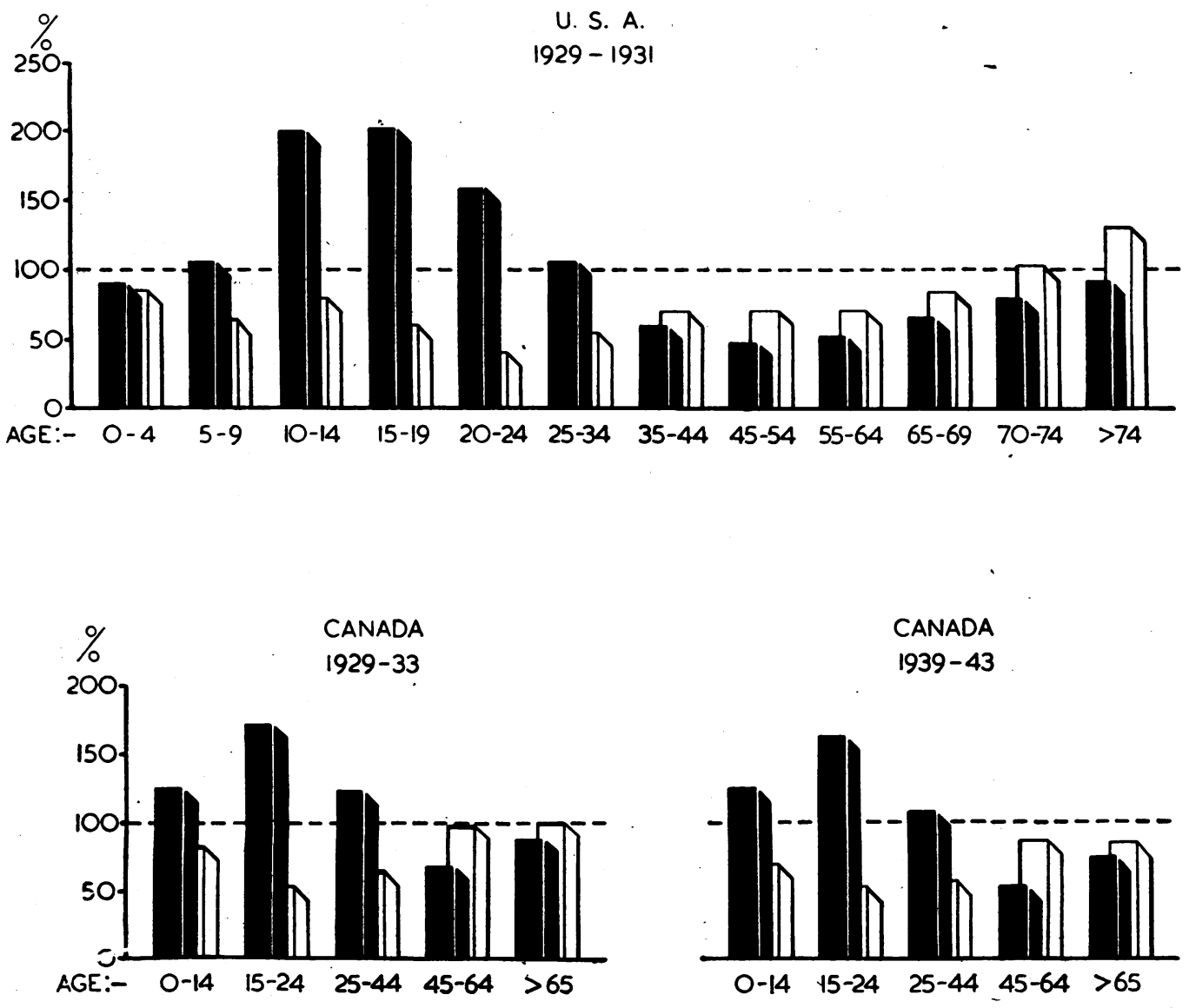

among women are shown as percentages of the corresponding rates among men of the same age group.

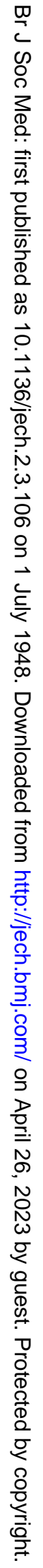


akin to that among other married women than to the corresponding ratio among single women.

The appropriate figures are shown below:

Ratio: BREAST to Uterus

\begin{tabular}{|c|c|c|c|}
\hline Age groups & $\begin{array}{l}\text { Never } \\
\text { married }\end{array}$ & $\begin{array}{l}\text { Married } \\
\text { without } \\
\text { children }\end{array}$ & $\begin{array}{l}\text { Married } \\
\text { with } \\
\text { children }\end{array}$ \\
\hline $\begin{array}{r}\text { Under } 35 \\
35-39 \\
40-44 \\
45-49 \\
50-54 \\
55-59 \\
60-64 \\
65-69 \\
70-74 \\
\text { Over } 74\end{array}$ & $\begin{array}{l}0 \cdot 77 \\
2 \cdot 78 \\
2 \cdot 18 \\
2 \cdot 16 \\
2 \cdot 24 \\
2 \cdot 27 \\
1 \cdot 80 \\
1 \cdot 75 \\
1 \cdot 90 \\
3 \cdot 25\end{array}$ & $\begin{array}{l}0 \cdot 57 \\
0 \cdot 50 \\
0 \cdot 97 \\
1 \cdot 00 \\
1 \cdot 09 \\
1 \cdot 19 \\
1 \cdot 15 \\
1 \cdot 23 \\
1 \cdot 64 \\
1 \cdot 83\end{array}$ & $\begin{array}{l}0 \cdot 69 \\
1 \cdot 00 \\
1 \cdot 31 \\
1 \cdot 15 \\
1 \cdot 12 \\
1 \cdot 03 \\
1 \cdot 18 \\
1 \cdot 17 \\
1 \cdot 26 \\
1 \cdot 50\end{array}$ \\
\hline
\end{tabular}

We are led to one of two conclusions: (a) that circumstances attendant on marriage as such, in contradistinction to procreation, exert some influence on cancer of the breast and of the uterus; $(b)$ that some obscure form of selection favours nuptiality among persons less prone to malignant disease at one site and more prone to malignant disease at the other. Separation of cancers of the uterus into those affecting the cervix and those affecting the body of the uterus might be revealing; but such a separation is not possible from available published figures.

Waterhouse (1948)* gives figures of the proportions of parous and nulliparous women treated for cancer of the cervix and for cancer of the body of the uterus in the Birmingham United Hospital (B.U.H.). Among those treated for cancer of the cervix the average number of children was $3 \cdot 8$, which is significantly different from the corresponding mean of 2.0 for the body of the uterus. In the following Table he cites also figures published in the Eighteenth Annual Report of the British Empire Cancer Campaign (B.E.C.C.):

\begin{tabular}{l|c|c|c|c|c}
\hline & & \multicolumn{2}{|c|}{ Cervix } & \multicolumn{2}{c}{ Body } \\
\cline { 3 - 6 } & & $\begin{array}{c}\text { B.U.H. } \\
(\%)\end{array}$ & $\begin{array}{c}\text { B.E.C.C. } \\
(\%)\end{array}$ & $\begin{array}{c}\text { B.U.H. } \\
(\%)\end{array}$ & $\begin{array}{c}\text { B.E.C.C. } \\
(\%)\end{array}$ \\
\hline Nulliparous &.. & 6 & 11 & 28 & 34 \\
Parous .. &.. & 78 & 85 & 47 & 56 \\
Unknown &.. & 16 & 4 & 25 & 10 \\
\hline
\end{tabular}

After allowing for the different proportions of " unknowns" in the two sets of figures, they are remarkably similar and show that the proportion

* Private communication. of nulliparous women with cancer of the cervix is 3 much lower than the proportion with cancer of $\stackrel{0}{?}$ the corpus uteri.

\section{Social Class Differentials}

Further evidence with respect to the effect of $\frac{\overline{\bar{m}}}{\mathrm{~s}}$ occupation or of environment on mortality is available in the Decennial Supplements of the Registrar General for England and Wales whiches contain figures of deaths from different diseases $\overrightarrow{0}$ among each social class. The Registrar General defines Social Class $I$ as consisting mainly of $\sigma^{\omega}$ professional men and women, Social Class III as consisting mainly of skilled artisans, and Social Class V as consisting of unskilled workers. Alli those who fall between these three main groups are $\omega$ in Social Classes II or IV. To facilitate comparison $\overrightarrow{8}$ the mortality experience of Social Classes I, III, and $\mathrm{V}$ only was investigated for those diseases which ${ }^{\circ}$ displayed a striking sex differential or a pronounced $\vec{c}$ difference between married and single women. Relevant figures are in Tables VIII (men), IX (single $\overrightarrow{-}$ women), and X (married women). Figures for $\frac{\infty}{\infty}$ single women in Social Class I are of doubtful significance since $(a)$ the population at risk is small, (b) the largest single occupation of women in Social Class $I$ is that of nuns, who are scarcelyo comparable with married women or with men in theo same social class. Among both men and women, $\varrho$ mortality from the three respiratory diseases quoted $\vec{O}$ is higher in Social Class V than in Social Class I. 3 This differential is most striking for bronchitis and least striking for pneumonia. On the other hand, neither peptic ulcer nor diabetes displays a very clear-cut differential. Mortality from the two last $\stackrel{\bigcirc}{\square}$ diseases in the oldest age groups is highest among men and women of Social Class I. Among younger: men and women, mortality from the two diseaseso is lowest in Social Class I.

Deaths from cancer of the breast and of the uterus윽 show the familiar opposing pattern, viz. mortality $>$ from the former is highest in Social Class I and을. from the latter in Social Class V; this is true of both married and single women.

\section{SUMMARY}

The aim of this paper is less to present decisive conclusions than to indicate a new attack upon the problem of sex differences, one which will throw light on their significance vis-áa-vis the nature- 0 nurture issue. If it offers few conclusions which are in fact decisive, it indicates a new line of profit- $\overrightarrow{\mathbb{Q}}$ able research when more copious and more reliable $\frac{}{\mathbb{1}}$ sources of official statistics become available. At $\cong$ the present time, the advent of a new Health Service 
TABLE II

Diseases with a Higher Male Mortality: at Ages Under fifteen Years

(Female rates as percentage of male rates)

A. ENGLAND AND WALES, 1930-1932

\begin{tabular}{lll|r|r|r}
\hline \multicolumn{1}{c|}{ Disease } & & & \multicolumn{3}{c}{ Age groups } \\
\cline { 5 - 6 } & & & $0-4$ & $5-9$ & $10-14$ \\
\hline Pneumonia (all) & $\ldots$ &. & $79 \cdot 0$ & $93 \cdot 3$ & $89 \cdot 5$ \\
Lobar pneumonia & $\ldots$ &. & $78 \cdot 7$ & $90 \cdot 5$ & $89 \cdot 6$ \\
Appendicitis .. & $\ldots$ &. & $71 \cdot 0$ & $77 \cdot 6$ & $70 \cdot 9$ \\
Bronchitis (all) &. &.. & $80 \cdot 8$ & $91 \cdot 3$ & $102 \cdot 0$ \\
& & & & & \\
\hline
\end{tabular}

B. CZEChOSLOVAKIA, 1928-1930

\begin{tabular}{|c|c|c|c|c|c|}
\hline \multirow{2}{*}{\multicolumn{4}{|c|}{ Disease }} & \multicolumn{2}{|c|}{ Age groups } \\
\hline & & & & $0-4$ & $5-14$ \\
\hline $\begin{array}{l}\text { Appendicitis } \\
\text { Acute nephritis } \\
\text { Bronchitis (all) . } \\
\qquad, \quad \text { (acute) } \\
\Rightarrow \quad \text { (chronic) }\end{array}$ & $\begin{array}{l}\cdots \\
\cdots \\
\cdots \\
\cdots \\
\cdots\end{array}$ & $\begin{array}{l}\cdots \\
\cdots \\
\cdots \\
\cdots\end{array}$ & $\begin{array}{l}\cdots \\
\cdots \\
\cdots \\
\cdots \\
\cdots\end{array}$ & $\begin{array}{l}66 \cdot 1 \\
74 \cdot 6 \\
83 \cdot 2 \\
83 \cdot 0 \\
84 \cdot 5\end{array}$ & $\begin{array}{r}98 \cdot 0 \\
86 \cdot 5 \\
220 \cdot 0 \\
185 \cdot 0 \\
243 \cdot 7\end{array}$ \\
\hline
\end{tabular}

C. NEW ZEALAND, 1930-1942

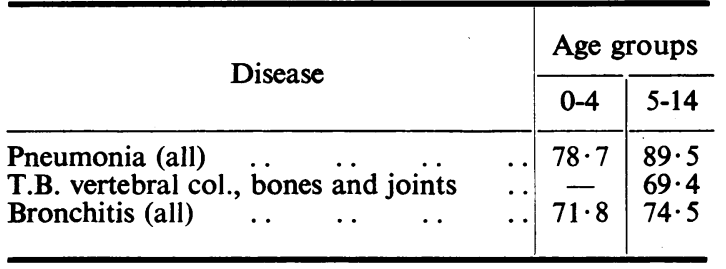

and of widespread recognition of what contribution statistical studies can make to the advancement of medicine offers a prospect which is encouraging from this point of view; but the extent to which the new situation will ensure more fruitful use of health statistics must depend on improvement of documentary design implemented with due regard to the potential outcome of comparison undertaken with a clearly-conceived biological objective. Pilot surveys of existing statistics may therefore be of value, if only by focusing attention on their deficiencies.

In viewing the outcome of the present study it will therefore be more profitable to draw attention to its deficiencies than to emphasize the positive findings which have emerged in the course of it. In any discussion of mortality statistics we should bear in mind that a relatively high mortality may be due to one or both of two circumstances: (a) a correspondingly high morbidity from the same disease; (b) a high fatality. In this context fatality
D. U.S.A., 1929-1931

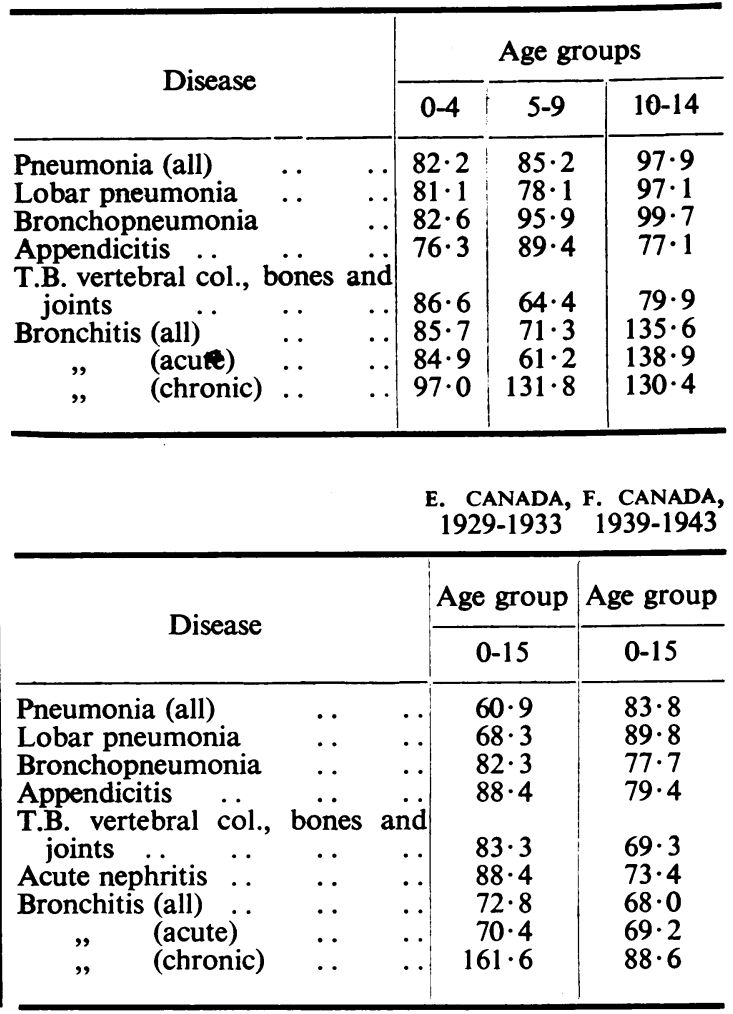

with respect to any disease signifies the risk of death among persons affected therewith. How far mortality differentials disclosed in this investigation are influenced by one or other of these two circumstances is impossible to determine in the absence of reliable statistics of the incidence of diseases. A differential morbidity with respect to infectious diseases can be caused by variations in exposure to risk, in the virulence of the infecting organism, or in degree of resistance offered by its host. It is unlikely that organisms invading one group of people are more virulent than those invading at the same time another group from the same community; nor have we any ground for believing that the physiological mechanism of resistance, that is, the ability of tissues to create antibodies, is affected by group differences such as sex or marital status. We may therefore suppose that groups of people distinguished by a differential incidence of clinical attacks of an infection are also distinguished by a differential exposure to risk or by variations in their 
TABLE III

Diseases with a Lower Mals Mortality at Ages Fifteen Years and Over (Female rates as percentage of male rates)

CZECHOSLOVAKIA, 1928-1930

\begin{tabular}{|c|c|c|c|c|c|c|c|c|}
\hline \multirow{2}{*}{\multicolumn{4}{|c|}{ Disease }} & \multicolumn{5}{|c|}{ Age'groups } \\
\hline & & & & $15-24$ & $25-39$ & $40-49$ & $50-64$ & $65-$ \\
\hline $\begin{array}{l}\text { Pernicious anaemia } \\
\text { Diseases of the thyroid and parathyroid }\end{array}$ & $\begin{array}{l}. \\
\cdots\end{array}$ & $\begin{array}{l}. \\
.\end{array}$ & $\cdots$ & $\begin{array}{l}224 \cdot 8 \\
228 \cdot 3\end{array}$ & $\begin{array}{l}237 \cdot 3 \\
421 \cdot 7\end{array}$ & $\begin{array}{l}138 \cdot 3 \\
444 \cdot 7\end{array}$ & $\begin{array}{l}104 \cdot 7 \\
272 \cdot 9\end{array}$ & $\begin{array}{l}126 \cdot 2 \\
238 \cdot 4\end{array}$ \\
\hline
\end{tabular}

U.S.A., 1929-1931

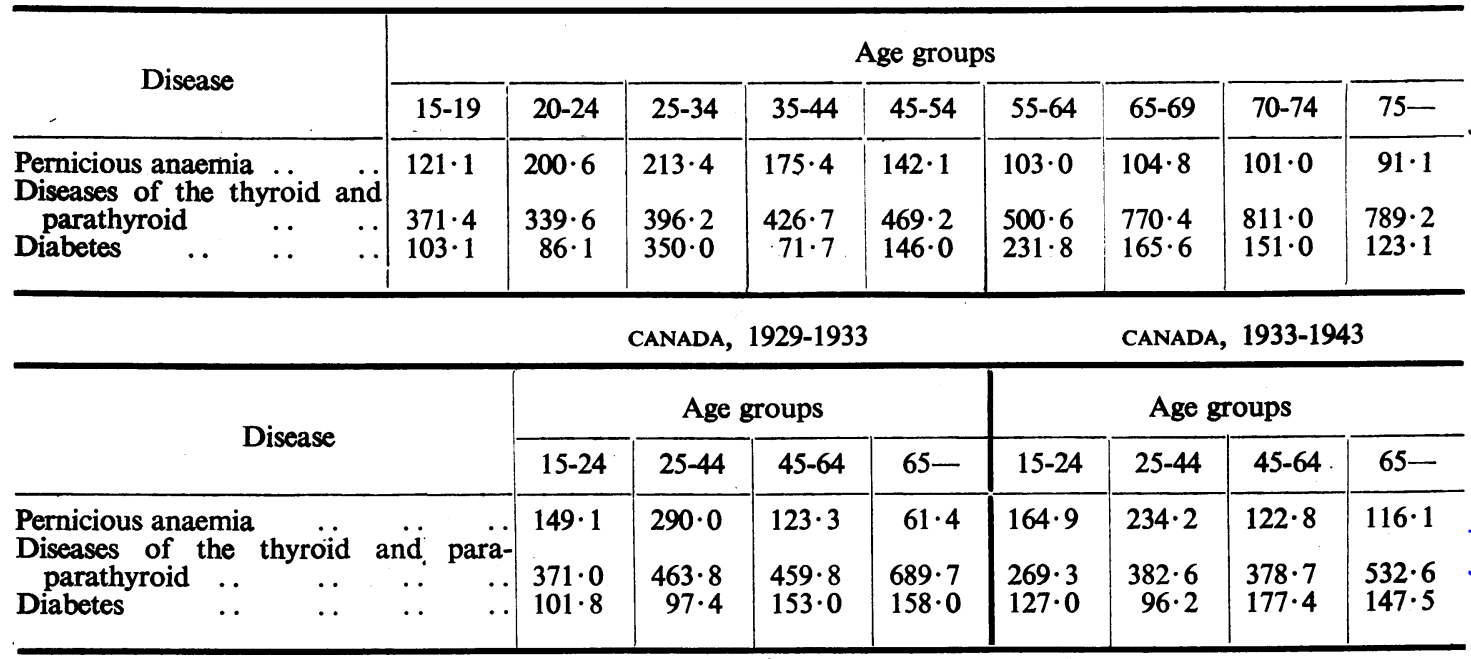

ENGLAND AND WALES, 1930-1932

\begin{tabular}{|c|c|c|c|c|c|c|c|c|c|}
\hline \multirow{2}{*}{ Disease } & \multicolumn{9}{|c|}{ Age groups } \\
\hline & $16-19$ & $20-24$ & $25-34$ & $35-44$ & $45-54$ & $55-64$ & $65-69$ & $70-74$ & $75-$ \\
\hline Diabetes & $106 \cdot 6$ & $89 \cdot 1$ & $87 \cdot 0$ & $110 \cdot 2$ & $126 \cdot 5$ & $141 \cdot 3$ & $128 \cdot 3$ & $104 \cdot 6$ & $88 \cdot 5$ \\
\hline
\end{tabular}

NEW ZEALAND, 1930-1942

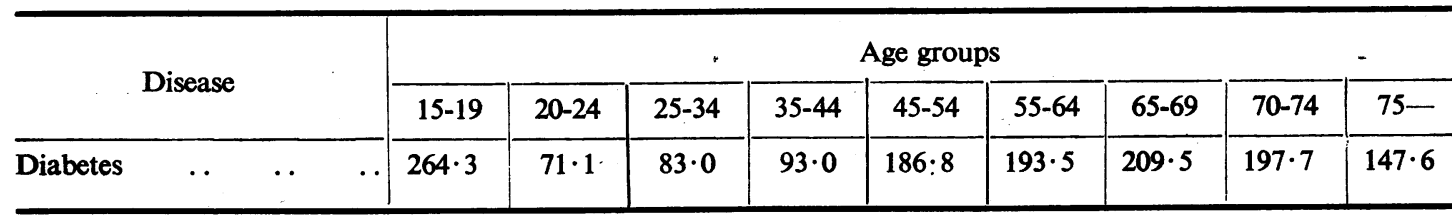


TABLE IV

Diseases with a Lower Male Mortality at Ages less than Fifteen Years (Female rates as percentage of male rates)

\begin{tabular}{|c|c|c|c|c|c|c|c|c|c|c|c|c|}
\hline A. ENGLAND ANI & \multicolumn{3}{|c|}{ WALES, 1930-1932 } & \multicolumn{2}{|c|}{$\begin{array}{l}\text { B. CZECHO- } \\
\text { SLOVAKIA, } \\
1928-1930\end{array}$} & \multicolumn{2}{|c|}{$\begin{array}{l}\text { C. NEW } \\
\text { ZEALAND, } \\
\text { 1930-1942 }\end{array}$} & \multicolumn{3}{|c|}{$\begin{array}{l}\text { D. U.S.A., } \\
\text { 1929-1931 }\end{array}$} & $\begin{array}{l}\text { E. CANADA, } \\
\text { 1929-1933 }\end{array}$ & $\begin{array}{l}\text { F. CANADA, } \\
1939-1943\end{array}$ \\
\hline \multirow{2}{*}{ Disease } & \multicolumn{3}{|c|}{ Age groups } & \multicolumn{2}{|c|}{ Age groups } & \multicolumn{2}{|c|}{ Age groups } & \multicolumn{3}{|c|}{ Age groups } & Age group & Age group \\
\hline & $0-4$ & $5-9$ & $10-14$ & $0-4$ & 5-14 & $0-4$ & $5-14$ & $0-4$ & $5-9$ & $10-14$ & $0-15$ & $0-15$ \\
\hline Whooping-cough & $\overline{128 \cdot 0}$ & $156 \cdot 9$ & $128 \cdot 0$ & $111 \cdot 1$ & $125 \cdot 2$ & $147 \cdot 4$ & $229 \cdot 6$ & $121 \cdot 0$ & 130.9 & $116 \cdot 3$ & $112 \cdot 9$ & $113 \cdot 4$ \\
\hline
\end{tabular}

resistance in so far as the latter can be affected by environmental circumstances such as inadequate nutrition or long hours of work.

Fatality per se may be influenced by the virulence of an infecting organism or by the degree of resistance of the host. For reasons given in the preceding paragraph, differential fatality will be associated mainly with variations with respect to resistance offered to infecting organisms by different groups of people. Whooping-cough, tuberculosis, acute nephritis, pneumonia, and bronchitis are noteworthy among infectious diseases responsible for differential mortality between the two sexes. Of these diseases, the last three are consistently higher among males, as is tuberculosis of bones and joints in all but the oldest age groups. Whooping-cough on the other hand, causes a consistently lower mortality among male children (Fig. 3). Of all males and females, those under the age of fifteen are most likely to share the same risk of exposure to infection, since they are both going to school, often to the same school. We therefore have reason to suspect that girls have a lower resistance to $B$. pertussis than do boys.

It is of interest that pneumonia, bronchitis, and tuberculosis of bones and joints, all of which cause a higher mortality among males, do so also among single women. They also cause a higher mortality in Social Class V than in Social Class I. We may suppose that occupational status has some bearing

\section{MORTALITY FROM WHOOPING COUGH}

\section{(Children under 15 years)}

RATE PER

$1,000,000$

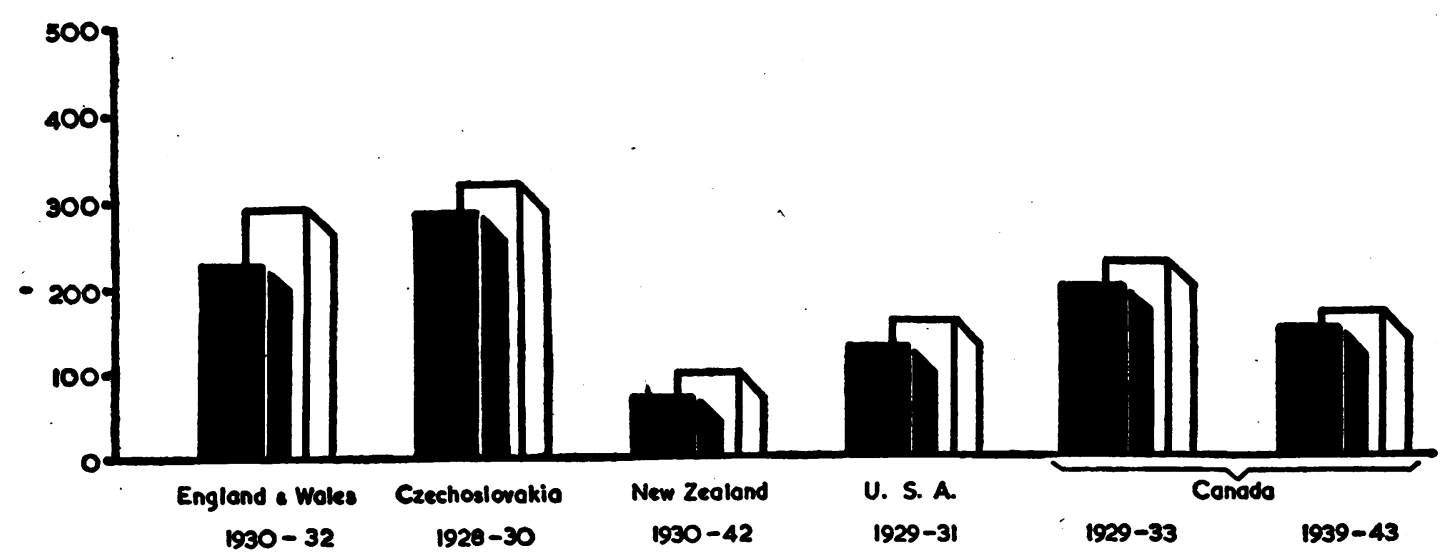

FIG. 3.-Mortality rates per $1,000,000$ population with respect to whooping-cough, among boys and girls of less than 15 years. 
TABLE V

TUBERCULOSIS MoRTALITY

(Female rates as percentage of male rates)

A. ENGLAND AND WALES, 1930-1932

\begin{tabular}{c|c|c|c|c|c|c|c|c|c|c|c|c}
\hline \multirow{2}{*}{ Disease } & \multicolumn{10}{|c|}{ Age groups } \\
\cline { 2 - 6 } & $0-4$ & $5-9$ & $10-14$ & $16-19$ & $20-24$ & $25-34$ & $35-44$ & $45-54$ & $55-64$ & $65-69$ & $70-74$ & $>74$ \\
\hline $\begin{array}{l}\text { Respiratory tuber- } \\
\text { culosis .. }\end{array}$ & $85 \cdot 6$ & $115 \cdot 6$ & $225 \cdot 9$ & $155 \cdot 2$ & $113 \cdot 7$ & $91 \cdot 8$ & $54 \cdot 6$ & $33 \cdot 2$ & $33 \cdot 6$ & $62 \cdot 5$ & $48 \cdot 6$ & $75 \cdot 2$ \\
\hline
\end{tabular}

B. Czechoslovakia, 1928-1930

\begin{tabular}{|c|c|c|c|c|c|c|c|c|}
\hline \multirow{2}{*}{ Disease } & & \multicolumn{7}{|c|}{ Age groups } \\
\hline & & $0-4$ & $5-14$ & $15-24$ & $25-39$ & $40-49$ & $50-64$ & $>64$ \\
\hline $\begin{array}{l}\text { Respiratory tuberculosis } \\
\text { T.B., vertebral col., bones and joints }\end{array}$ & $\begin{array}{ll}\ldots & . . \\
. & . .\end{array}$ & $\begin{array}{l}83 \cdot 4 \\
84 \cdot 6\end{array}$ & $\begin{array}{r}144 \cdot 7 \\
66 \cdot 6\end{array}$ & $\begin{array}{r}119 \cdot 4 \\
54 \cdot 0\end{array}$ & $\begin{array}{l}91 \cdot 4 \\
77 \cdot 2\end{array}$ & $\begin{array}{r}57 \cdot 8 \\
109 \cdot 5\end{array}$ & $\begin{array}{r}55 \cdot 6 \\
145 \cdot 4\end{array}$ & $\begin{array}{r}72 \cdot 9 \\
177 \cdot 0\end{array}$ \\
\hline
\end{tabular}

C. NEW ZEALAND, 1930-1942

\begin{tabular}{l|r|r|r|r|r|r|r|r|r|r|r}
\hline \multirow{2}{*}{ Disease } & \multicolumn{10}{|c|}{ Age groups } \\
\cline { 2 - 9 } & $0-4$ & $5-14$ & $15-19$ & $20-24$ & $25-34$ & $35-44$ & $45-54$ & $55-64$ & $65-69$ & $70-74$ & $>74$ \\
\hline $\begin{array}{l}\text { Respiratory tuber- } \\
\text { culosis . . }\end{array}$ & $33 \cdot 6$ & $141 \cdot 9$ & $252 \cdot 6$ & $191 \cdot 9$ & $136 \cdot 0$ & $66 \cdot 4$ & $44 \cdot 1$ & $36 \cdot 2$ & $33 \cdot 3$ & $45 \cdot 5$ & $66 \cdot 5$ \\
$\begin{array}{r}\text { T.B., vertebral coi., } \\
\text { bones and joints }\end{array}$ & - & $69 \cdot 4$ & $51 \cdot 9$ & $55 \cdot 4$ & $61 \cdot 4$ & $45 \cdot 7$ & $45 \cdot 4$ & $114 \cdot 9$ & $179 \cdot 5$ & $17 \cdot 8$ & $498 \cdot 9$ \\
\hline
\end{tabular}

D. U.S.A., 1929-1931

\begin{tabular}{|c|c|c|c|c|c|c|c|c|c|c|c|c|}
\hline \multirow{2}{*}{ Disease } & \multicolumn{12}{|c|}{ Age groups } \\
\hline & $0-4$ & $5-9$ & $10-14$ & $15-19$ & $\overline{20-24}$ & $25-34$ & $35-44$ & $45-54$ & $55-64$ & $65-69$ & $70-74$ & $>74$ \\
\hline Respiratory tuberculosis & $90 \cdot 2$ & $107 \cdot 0$ & $200 \cdot 0$ & $202 \cdot 5$ & $\overline{-157 \cdot 4}$ & $\overline{106 \cdot 1}$ & $61 \cdot 3$ & $47 \cdot 7$ & $52 \cdot 8$ & $65 \cdot 9$ & $79 \cdot 1$ & $92 \cdot 0$ \\
\hline joints & $86 \cdot 6$ & $64 \cdot 4$ & $79 \cdot 9$ & $61 \cdot 4$ & $40 \cdot 2$ & $55 \cdot 2$ & $71 \cdot 1$ & $70 \cdot 1$ & $71 \cdot 0$ & $84 \cdot 1$ & $103 \cdot 0$ & $130 \cdot 4$ \\
\hline
\end{tabular}

E. CANADA, 1929-1933

F. CANADA, 1939-1943

\begin{tabular}{|c|c|c|c|c|c|c|c|c|c|c|c|}
\hline \multirow{2}{*}{ Disease } & \multicolumn{6}{|c|}{ Age groups } & \multicolumn{5}{|c|}{ Age groups } \\
\hline & & $0-14$ & $15-24$ & $25-44$ & $45-64$ & $>64$ & $0-14$ & $15-24$ & $25-44$ & $45-64$ & $>84$ \\
\hline $\begin{array}{l}\text { Respiratory tuberculosis } \\
\text { T.B., vertebral col., bones and joints }\end{array}$ & $\cdots$ & $\begin{array}{r}126 \cdot 4 \\
83 \cdot 3\end{array}$ & $\begin{array}{r}172 \cdot 8 \\
53 \cdot 9\end{array}$ & $\begin{array}{r}124.0 \\
64.9\end{array}$ & $\begin{array}{l}67 \cdot 7 \\
98 \cdot 0\end{array}$ & $\begin{array}{r}87 \cdot 0 \\
100 \cdot 3\end{array}$ & $\begin{array}{r}125 \cdot 5 \\
69 \cdot 3\end{array}$ & $\begin{array}{r}162 \cdot 4 \\
53 \cdot 2\end{array}$ & $\begin{array}{r}108 \cdot 1 \\
.56 \cdot 4\end{array}$ & $\begin{array}{l}53 \cdot 0 \\
86 \cdot 2\end{array}$ & $\begin{array}{l}74 \cdot 1 \\
84 \cdot 3\end{array}$ \\
\hline
\end{tabular}


TABLE VI

Diseases with a Higher Mortality among Married Women (Married women as percentage of single women)

ENGLAND AND WALES, 1930-1932

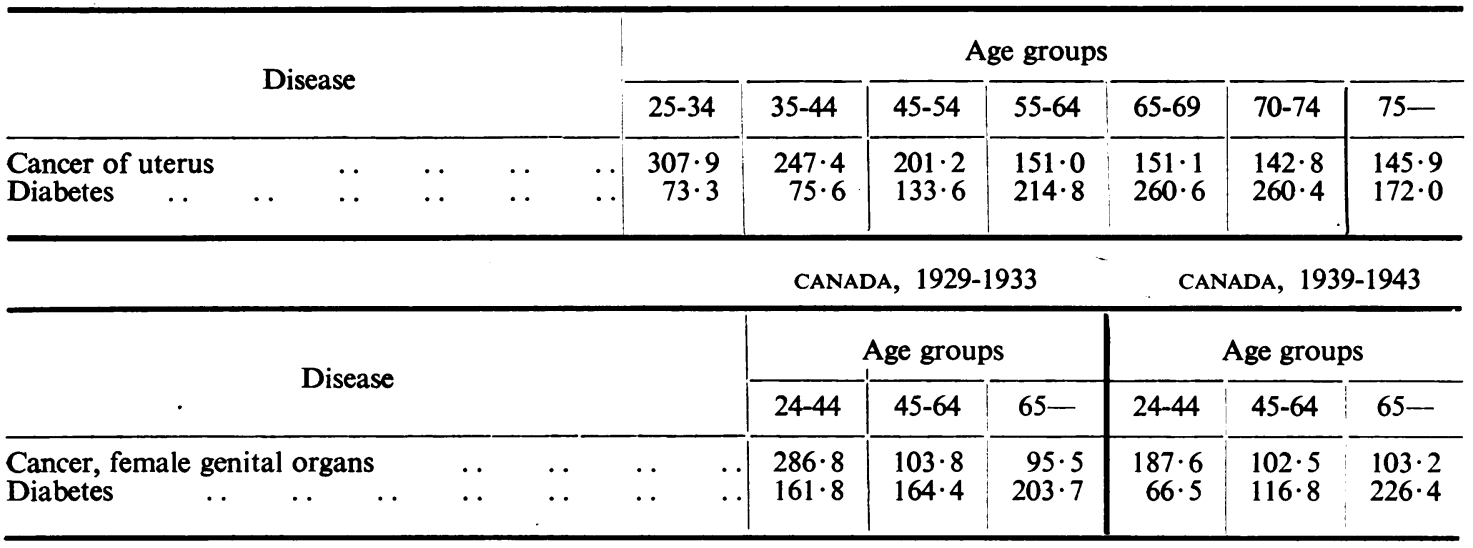

TABLE VII

Diseases With a Lower Mortality among Married Women (Married women as percentage of single women)

ENGLAND AND WALES, 1930-1932

\begin{tabular}{|c|c|c|c|c|c|c|c|c|c|c|c|c|}
\hline \multirow{2}{*}{\multicolumn{6}{|c|}{ Disease }} & \multicolumn{7}{|c|}{ Age groups } \\
\hline & & & & & & $25-34$ & $35-44$ & $45-54$ & $55-64$ & $65-69$ & $70-74$ & $75-$ \\
\hline $\begin{array}{l}\text { Respiratory tube } \\
\text { Peptic ulcer. } \\
\text { Cancer of the br } \\
\text { Bronchitis . } \\
\text { Pneumonia (ail) } \\
\text { Suicide .. }\end{array}$ & $\begin{array}{l}\text { ulosis } \\
\ldots \\
\text { st } \\
\ldots \\
\ldots\end{array}$ & $\begin{array}{l}\cdots \\
\cdots \\
\cdots \\
\cdots \\
\cdots\end{array}$ & $\begin{array}{l}\cdots \\
\cdots \\
\cdots \\
\cdots \\
\cdots\end{array}$ & $\begin{array}{l}\cdots \\
\cdots \\
\cdots \\
\cdots \\
\cdots\end{array}$ & \begin{tabular}{l|}
$\cdots$ \\
$\cdots$ \\
$\cdots$ \\
$\cdots$ \\
$\cdots$
\end{tabular} & $\begin{array}{r}70 \cdot 6 \\
89 \cdot 1 \\
149 \cdot 2 \\
70 \cdot 9 \\
113 \cdot 2 \\
74 \cdot 3\end{array}$ & $\begin{array}{l}79 \cdot 4 \\
72 \cdot 0 \\
88 \cdot 1 \\
76 \cdot 0 \\
95 \cdot 1 \\
71 \cdot 0\end{array}$ & $\begin{array}{l}85 \cdot 7 \\
79 \cdot 9 \\
72 \cdot 6 \\
95 \cdot 0 \\
72 \cdot 6 \\
71 \cdot 5\end{array}$ & $\begin{array}{r}94 \cdot 7 \\
78 \cdot 0 \\
72 \cdot 8 \\
104 \cdot 1 \\
79 \cdot 7 \\
75 \cdot 5\end{array}$ & $\begin{array}{r}82 \cdot 3 \\
79 \cdot 4 \\
73 \cdot 4 \\
125 \cdot 6 \\
98 \cdot 1 \\
83 \cdot 8\end{array}$ & $\begin{array}{r}87 \cdot 1 \\
90 \cdot 4 \\
67 \cdot 7 \\
108 \cdot 2 \\
107 \cdot 9 \\
88 \cdot 5\end{array}$ & $\begin{array}{l}93 \cdot 8 \\
68 \cdot 9 \\
67 \cdot 7 \\
87 \cdot 5 \\
73 \cdot 2 \\
71 \cdot 2\end{array}$ \\
\hline
\end{tabular}

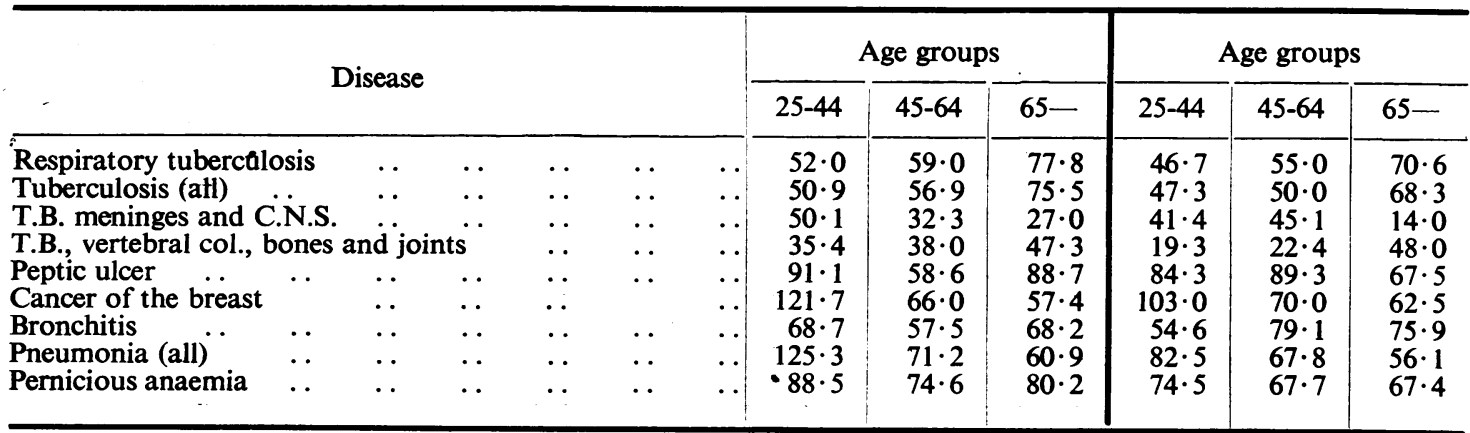


TABLE VIII

Mean Annual Mortality Rates per 1,000,000 among Men of England and Wales, 1930-1932

\begin{tabular}{|c|c|c|c|c|c|c|c|c|c|c|c|}
\hline \multirow{2}{*}{\multicolumn{3}{|c|}{ Disease }} & \multirow{2}{*}{$\begin{array}{c}\text { Social } \\
\text { Class }\end{array}$} & \multicolumn{8}{|c|}{ Age groups } \\
\hline & & & & $20-24$ & $25-34$ & $35-44$ & $45-54$ & $55-64$ & $65-69$ & $70-74$ & $>74$ \\
\hline Respiratory & tuberc & losis & $\underset{\text { III }}{\text { I }}$ & $\begin{array}{r}551 \\
1,042 \\
1,196\end{array}$ & $\begin{array}{r}625 \\
1,100 \\
1,210\end{array}$ & $\begin{array}{r}869 \\
1,251 \\
1,626\end{array}$ & $\begin{array}{r}805 \\
1,524 \\
2,015\end{array}$ & $\begin{array}{r}879 \\
1,285 \\
1,727\end{array}$ & $\begin{array}{r}703 \\
908 \\
1,327\end{array}$ & $\begin{array}{l}472 \\
600 \\
900\end{array}$ & $\begin{array}{l}474 \\
268 \\
458\end{array}$ \\
\hline Bronchitis & .. & .. & $\underset{\text { V }}{\text { III }}$ & $\begin{array}{l}\overline{22} \\
39\end{array}$ & $\begin{array}{r}6 \\
29 \\
52\end{array}$ & $\begin{array}{r}25 \\
116 \\
227\end{array}$ & $\begin{array}{l}122 \\
342 \\
647\end{array}$ & $\begin{array}{r}287 \\
815 \\
1,272\end{array}$ & $\begin{array}{r}687 \\
2,050 \\
3,139\end{array}$ & $\begin{array}{l}1,488 \\
4,382 \\
6,440\end{array}$ & $\begin{array}{r}5,693 \\
13,070 \\
17,399\end{array}$ \\
\hline Pneumonia & .. & .. & $\underset{\text { III }}{\text { I }}$ & $\begin{array}{l}107 \\
179 \\
241\end{array}$ & $\begin{array}{l}183 \\
224 \\
350\end{array}$ & $\begin{array}{l}405 \\
500 \\
807\end{array}$ & $\begin{array}{r}807 \\
839 \\
1,359\end{array}$ & $\begin{array}{r}988 \\
1,229 \\
1,738\end{array}$ & $\begin{array}{l}1,599 \\
1,873 \\
2,677\end{array}$ & $\begin{array}{l}2,526 \\
2,609 \\
3,384\end{array}$ & $\begin{array}{l}5,377 \\
4,394 \\
5,574\end{array}$ \\
\hline Peptic ulcer & .. & .. & $\underset{\text { III }}{\text { I }}$ & $\begin{array}{l}15 \\
44 \\
36\end{array}$ & $\begin{array}{r}50 \\
75 \\
113\end{array}$ & $\begin{array}{r}64 \\
192 \\
284\end{array}$ & $\begin{array}{l}292 \\
378 \\
453\end{array}$ & $\begin{array}{l}391 \\
461 \\
451\end{array}$ & $\begin{array}{l}608 \\
497 \\
404\end{array}$ & $\begin{array}{l}723 \\
560 \\
506\end{array}$ & $\begin{array}{l}896 \\
517 \\
385\end{array}$ \\
\hline Diabetes & . & . & $\underset{\text { III }}{\text { I }}$ & $\begin{array}{r}-18 \\
22\end{array}$ & $\begin{array}{l}22 \\
28 \\
40\end{array}$ & $\begin{array}{l}15 \\
43 \\
44\end{array}$ & $\begin{array}{r}137 \\
91 \\
62\end{array}$ & $\begin{array}{l}442 \\
315 \\
177\end{array}$ & $\begin{array}{l}991 \\
705 \\
341\end{array}$ & $\begin{array}{r}1,700 \\
1,000 \\
667\end{array}$ & $\begin{array}{r}2,926 \\
1,085 \\
688\end{array}$ \\
\hline
\end{tabular}

TABLE IX

Mean Annual Mortality Rates per 1,000,000 among Single Women of England and Wales, 1930-1932

\begin{tabular}{|c|c|c|c|c|c|c|c|c|c|}
\hline \multirow{2}{*}{ Disease } & \multirow{2}{*}{$\begin{array}{l}\text { Social } \\
\text { Class }\end{array}$} & \multicolumn{8}{|c|}{ Age groups } \\
\hline & & $20-24$ & $25-34$ & $35-44$ & $45-54$ & $55-64$ & $65-69$ & $70-74$ & $>74$ \\
\hline Respiratory tuberculosis & III & $\begin{array}{l}1,122 \\
1,071 \\
1,479\end{array}$ & $\begin{array}{r}665 \\
1,158 \\
1,154\end{array}$ & $\begin{array}{r}1,516 \\
818 \\
996\end{array}$ & $\begin{array}{l}887 \\
585 \\
908\end{array}$ & $\begin{array}{r}1,044 \\
559 \\
700\end{array}$ & $\begin{array}{l}470 \\
507 \\
474\end{array}$ & $\begin{array}{c}1,270 \\
353 \\
-\end{array}$ & $\begin{array}{r}1,930 \\
432 \\
1,142\end{array}$ \\
\hline Bronchitis $\quad .$. & $\underset{\text { V }}{\text { III }}$ & $\begin{array}{l}-\overline{11} \\
19\end{array}$ & $\begin{array}{c}- \\
17 \\
52\end{array}$ & $\begin{array}{r}- \\
48 \\
238\end{array}$ & $\begin{array}{l}111 \\
141 \\
260\end{array}$ & $\begin{array}{l}447 \\
518 \\
744\end{array}$ & $\begin{array}{l}1,410 \\
1,403 \\
2,053\end{array}$ & $\begin{array}{l}1,904 \\
4,506 \\
7,705\end{array}$ & $\begin{array}{l}11,582 \\
15,667 \\
29,107\end{array}$ \\
\hline Pneumonia .. & $\underset{\text { III }}{\text { I }}$ & $\begin{array}{l}-79 \\
88\end{array}$ & $\begin{array}{l}133 \\
118 \\
165\end{array}$ & $\begin{array}{l}178 \\
225 \\
522\end{array}$ & $\begin{array}{l}776 \\
442 \\
487\end{array}$ & $\begin{array}{r}745 \\
940 \\
1,367\end{array}$ & $\begin{array}{l}1,880 \\
1,598 \\
3,317\end{array}$ & $\begin{array}{l}1,270 \\
2,739 \\
5,694\end{array}$ & $\begin{array}{r}5,791 \\
6,478 \\
11,414\end{array}$ \\
\hline Peptic ulcer & III & $\begin{array}{r}- \\
13\end{array}$ & $\begin{array}{c}-\overline{18} \\
10\end{array}$ & $\begin{array}{r}\overline{51} \\
143\end{array}$ & $\begin{array}{r}222 \\
141 \\
97\end{array}$ & $\begin{array}{r}447 \\
212 \\
44\end{array}$ & $\begin{array}{l}470 \\
273 \\
158\end{array}$ & $\begin{array}{l}\overline{230} \\
670\end{array}$ & $\overline{336}$ \\
\hline Diabetes & $\underset{\text { III }}{\text { II }}$ & $\begin{array}{r}-13 \\
13\end{array}$ & $\begin{array}{l}67 \\
18 \\
21\end{array}$ & $\begin{array}{l}-28 \\
95\end{array}$ & $\begin{array}{r}441 \\
63 \\
227\end{array}$ & $\begin{array}{r}-82 \\
569\end{array}$ & $\begin{array}{l}470 \\
250 \\
158\end{array}$ & $\begin{array}{r}635 \\
604 \\
1,340\end{array}$ & $\begin{array}{c}2,574 \\
672 \\
-\end{array}$ \\
\hline Cancer of the uterus & $\underset{\text { III }}{\text { I }}$ & $\bar{z}$ & $\begin{array}{r}- \\
14 \\
10\end{array}$ & $\begin{array}{r}-93 \\
142\end{array}$ & $\begin{array}{l}554 \\
234 \\
422\end{array}$ & $\begin{array}{l}149 \\
472 \\
657\end{array}$ & $\begin{array}{r}470 \\
624 \\
1,264\end{array}$ & $\begin{array}{l}\overline{972} \\
670\end{array}$ & $\begin{array}{l}1,287 \\
1,200 \\
1,712\end{array}$ \\
\hline Cancer of the breast & $\underset{\text { V }}{\text { III }}$ & $=$ & $\begin{array}{l}\overline{20} \\
41\end{array}$ & $\begin{array}{r}89 \\
235 \\
285\end{array}$ & $\begin{array}{r}1,219 \\
718 \\
649\end{array}$ & $\begin{array}{r}1,491 \\
1,275 \\
569\end{array}$ & $\begin{array}{l}1,880 \\
1,685 \\
2,685\end{array}$ & $\begin{array}{l}4,444 \\
2,244 \\
1,675\end{array}$ & $\begin{array}{l}8,365 \\
3,479 \\
2,854\end{array}$ \\
\hline
\end{tabular}


TABLE $\mathbf{X}$

Mean Annual Mortality Rates per 1,000,000 among Married Women of Engla nd and Wales, 1930-1932

\begin{tabular}{|c|c|c|c|c|c|c|c|c|c|c|c|c|}
\hline \multirow{2}{*}{\multicolumn{3}{|c|}{ Disease }} & \multirow{2}{*}{\multicolumn{2}{|c|}{$\begin{array}{l}\text { Social } \\
\text { Class }\end{array}$}} & \multicolumn{8}{|c|}{ Age groups } \\
\hline & & & & & $20-24$ & $25-34$ & $35-44$ & $45-54$ & $55-64$ & $65-69$ & $70-74$ & $>74$ \\
\hline \multicolumn{4}{|c|}{ Respiratory tuberculosis } & $\underset{\text { V }}{\text { III }}$ & $\begin{array}{r}538 \\
1,031 \\
1,262\end{array}$ & $\begin{array}{r}412 \\
857 \\
1,139\end{array}$ & $\begin{array}{l}305 \\
652 \\
903\end{array}$ & $\begin{array}{l}281 \\
485 \\
658\end{array}$ & $\begin{array}{l}285 \\
425 \\
535\end{array}$ & $\begin{array}{l}213 \\
368 \\
462\end{array}$ & $\begin{array}{l}283 \\
206 \\
318\end{array}$ & $\begin{array}{l}410 \\
224 \\
213\end{array}$ \\
\hline Bronchitis & . & $\cdots$ & . & III & -6 & $\begin{array}{r}7 \\
22 \\
30 \\
\end{array}$ & $\begin{array}{l}16 \\
43 \\
74\end{array}$ & $\begin{array}{r}39 \\
133 \\
199\end{array}$ & $\begin{array}{l}117 \\
454 \\
724 \\
\end{array}$ & $\begin{array}{r}426 \\
1,369 \\
1,983 \\
\end{array}$ & $\begin{array}{r}737 \\
3,151 \\
4,221 \\
\end{array}$ & $\begin{array}{r}3,692 \\
8,111 \\
10,915 \\
\end{array}$ \\
\hline Pneumonia & .. & $\cdots$ & & $\underset{V}{\text { III }}$ & $\begin{array}{l}134 \\
133 \\
186\end{array}$ & $\begin{array}{r}99 \\
146 \\
242\end{array}$ & $\begin{array}{l}176 \\
236 \\
338\end{array}$ & $\begin{array}{l}209 \\
321 \\
428\end{array}$ & $\begin{array}{l}528 \\
627 \\
800\end{array}$ & $\begin{array}{r}883 \\
1,225 \\
1,558\end{array}$ & $\begin{array}{l}1,304 \\
1,990 \\
2,194\end{array}$ & $\begin{array}{l}2,871 \\
3,220 \\
3,271\end{array}$ \\
\hline Peptic ulcer & .. & . & & $\underset{\text { III }}{I}$ & $\begin{array}{r}67 \\
11 \\
8 \\
\end{array}$ & $\begin{array}{l}14 \\
18 \\
20 \\
\end{array}$ & $\begin{array}{r}26 \\
36 \\
45 \\
\end{array}$ & $\begin{array}{r}22 \\
90 \\
102 \\
\end{array}$ & $\begin{array}{r}92 \\
118 \\
145 \\
\end{array}$ & $\begin{array}{l}122 \\
209 \\
130 \\
\end{array}$ & $\begin{array}{l}227 \\
182 \\
166 \\
\end{array}$ & $\begin{array}{r}410 \\
243 \\
36 \\
\end{array}$ \\
\hline Diabetes & . & $\cdots$ & & $\underset{\text { V }}{\text { III }}$ & $\begin{array}{r}-28 \\
4\end{array}$ & $\begin{array}{l}14 \\
25 \\
32 \\
\end{array}$ & $\begin{array}{l}21 \\
43 \\
44 \\
\end{array}$ & $\begin{array}{r}55 \\
125 \\
143 \\
\end{array}$ & $\begin{array}{l}318 \\
549 \\
531\end{array}$ & $\begin{array}{r}852 \\
1,125 \\
1,031\end{array}$ & $\begin{array}{l}1,513 \\
1,438 \\
1,332\end{array}$ & $\begin{array}{r}2,564 \\
1,410 \\
\quad 996\end{array}$ \\
\hline Cancer of th & uterus & & & III & $\begin{array}{r}- \\
6 \\
4 \\
\end{array}$ & $\begin{array}{l}\overline{33} \\
65 \\
\end{array}$ & $\begin{array}{l}119 \\
197 \\
294\end{array}$ & $\begin{array}{l}264 \\
438 \\
591\end{array}$ & $\begin{array}{l}469 \\
635 \\
754 \\
\end{array}$ & $\begin{array}{l}670 \\
750 \\
779 \\
\end{array}$ & $\begin{array}{l}624 \\
859 \\
984\end{array}$ & $\begin{array}{r}410 \\
1,083 \\
960\end{array}$ \\
\hline Cancer of the & breast & & & $\underset{\text { III }}{\mathbf{I}}$ & -1 & $\begin{array}{r}7 \\
30 \\
32\end{array}$ & $\begin{array}{l}269 \\
203 \\
162\end{array}$ & $\begin{array}{l}715 \\
546 \\
420\end{array}$ & $\begin{array}{r}1,164 \\
842 \\
685\end{array}$ & $\begin{array}{r}1,613 \\
1,026 \\
772\end{array}$ & $\begin{array}{r}1,190 \\
1,180 \\
984\end{array}$ & $\begin{array}{l}1,743 \\
1,680 \\
1,387\end{array}$ \\
\hline
\end{tabular}

TABLE XI

Infertility of Deceased Married Women distinguishing Certain Causes of Death (Infertile per 1,000 stated)

\begin{tabular}{c|c|c|c|c|c}
\hline $\begin{array}{c}\text { Age of woman at } \\
\text { death }\end{array}$ & $\begin{array}{c}\text { All causes of } \\
\text { death }\end{array}$ & Tuberculosis & Cancer of uterus & Cancer of breast & Diabetes \\
\hline Under 25 & 455 & 496 & - & $\overline{2}$ & - \\
$25-34$ & 296 & 317 & 193 & 240 & -168 \\
$35-44$ & 214 & 222 & 136 & 213 & 180 \\
$455-54$ & 188 & 177 & 179 & 204 & 92 \\
$55-64$ & 160 & 167 & 153 & 167 & 87 \\
$65-74$ & 142 & 96 & 162 & 241 & 117 \\
75 and over & 150 & - & & & \\
\hline
\end{tabular}


either on exposure to infection or on the ability of the individual to resist invading organisms; but so little is known of the influence of environment on an individual's resistance to disease that it would be dangerous to speculate on the basis of such inconclusive data. A knowledge of the contributions of morbidity and fatality to the mortality differentials of these groups would undoubtedly throw some light on their causation.

Whereas variations in exposure to and in individual resistance to infection provide a fairly clear-cut explanation of mortality differentials with respect to diseases due to infection, we have no such basis of scientific knowledge on which to build theories about the cause of mortality differentials with respect to other diseases. We may postulate that differences of temperament as well as of environment play a part not only in the course of a disease but also in its causation. The susceptibility of London bus drivers to peptic ulcers is well known. Unfortunately, we have no means of telling how far this is due to circumstances other than an occupation at present peculiar to the male sex, until the London Passenger Transport Board begin to employ women drivers. A sufficient body of information exists to convince us that the incidence of peptic ulceration as well as mortality from it is two or three times higher among men than among women. If certain occupations do predispose to peptic ulcers, marriage appears to be one of the least hazardous in this respect; and inasmuch as it carries with it no great risk of unemployment and does not demand adherence to a rigid time-schedule, this may well be so.

On the other hand, marriage does appear to predispose to diabetes and Table XI provides some evidence that the high mortality from this disease among married women is associated to some extent with childbearing. This Table, which was extracted from the Registrar General's Statistical Review of England and Wales for 1945, shows the proportion of childless to all married women who died during 1945 from various causes. Proportions based on between 50 and 250 cases are shown in italics, and those based on less than 50 cases are omitted. Other figures are therefore fairly reliable. In the two decades 55-64 and 65-74, the proportion of childless married women was very much lower among those dying from diabetes than among those dying from any other cause specified, or from all causes. Repeated adjustments to metabolism of the mother demanded by successive pregnancies presumably have some adverse influence on the ability of hero pancreas or liver to function efficiently.

On the whole, however, marriage appears to $\mathrm{be}_{\overline{\mathrm{s}}}$ a healthy occupation, since married women suffer? a higher mortality than single women and men from only two diseases-diabetes and cancer of $\overline{\frac{\bar{m}}{5}}$. the uterus. With the exception of appendicitis, $\frac{\overrightarrow{\mathbb{D}}}{\mathrm{D}}$ every disease which causes a higher mortality among men than among women also causes a higheres mortality among single women than among those $\vec{\circ}$ who are married. Since any agency traceable to the X-chromosome complement is certainly unal- $\vec{\omega}$ tered by marriage, occupation must play no little part in determining a differential risk of these $\frac{\rho}{\zeta}$ diseases to men and women. Reliable statisticsin with respect to the incidence of disease, when they become available, can throw more light on this $\vec{\circ}$ problem by providing a means of assessing $(a)$ the $\mathrm{o}_{0}$ contributions of morbidity and fatality to differential ${ }^{\circ}$ mortality, (b) existing differentials between men, $\vec{c}$ single women, and married women with respect to diseases which are rarely fatal.

It is a pleasure to acknowledge our indebtedness to Professor Hilda Lloyd and to Mr. C. C. M. James for constructive comments. We also wish to thank Profes-o sor Lancelot Hogben for his constant encouragement and advice.:

\section{REFERENCES}

Metropolitan Life Insurance Company (1945). Statisti-으 cal Bulletin, Volume 26, number 9. New York.

Rich, Arnold R. (1946). "The Pathogenesis of Tuber- 3 culosis." Springfield, Illinois.

Commonwealth Bureau of Census and Statistics.0 Australian Demography. Bulletins nos. 49-53. 1931-1935. Canberra.

Dominion Bureau of Statistics, Canada. Vital Statistics, $\stackrel{\odot}{.}$ 1929-1933, 1939-1943. Annual Reports. Ottawa.o

Office de Statistique (1936). "Mouvement de la?. Population en Tchécoslovaquie au cours des années 1928-1930." Prague.

The Registrar General's Decennial Supplement. England and Wales, 1931. Part IIa. Occupational Mortality. H.M.S.O. 1938.

The Registrar General's Statistical Review of England을 and Wales for the years 1930-1932 (New Annual Series Nos. 10-12). Tables Part I Medical. H.M.S.O.O 1931-1933.

The Registrar General's Statistical Review of England and Wales for the year 1945 (New Annual Seriesw No. 25). Tables Part II Civil. H.M.S.O. 1948 ర

Census and Statistics Office. Report on the Vitalo Statistics of the Dominion of New Zealand for the years 1930-1942. Annual reports. Wellington. \&

Department of Commerce. Vital Statistics of the United States. 1929-1931. Annual reports. Washington, D.C. 